University of Warwick institutional repository: http://go.warwick.ac.uk/wrap This paper is made available online in accordance with publisher policies. Please scroll down to view the document itself. Please refer to the repository record for this item and our policy information available from the repository home page for further information.

To see the final version of this paper please visit the publisher's website. Access to the published version may require a subscription.

Author(s): Alan Felstead, Nick Jewson, Annie Phizacklea and Sally Walters

Article Title: Working at Home: Statistical Evidence for Seven

Key Hypotheses

Year of publication: 2001

Link to published version: http://dx.doi.org/10.1177/09500170122118922

Publisher statement: None 


\title{
Working at Home: Statistical Evidence for Seven Key Hypotheses
}

\author{
Alan Felstead, Nick Jewson, Annie Phizacklea and Sally Walters \\ University of University of University of University of \\ Leicester Leicester Warwick Leicester
}

\begin{abstract}
It is frequently suggested that working at home will be the future of work for many people in the UK and that trends in this direction are already well underway. This paper examines these claims by analysing data from the Labour Force Survey which has, at various times, asked questions about the location of work. Seven key hypotheses are identified, including issues surrounding the extent and growth of working at home, reliance on information and communication technology, prevalence of low pay, average pay rates, gender issues, ethnic minority participation and household composition. The results paint a variegated and complex picture which suggests that those who work at home do not comprise a homogeneous group. The paper in particular highlights differences between non-manual and manual workers, and those who work mainly, partially and sometimes at home.
\end{abstract}

The vision of more and more people working at home is an enduring feature of the popular debate about the future of work. Rarely a week goes by without at least one news item on the topic appearing in the national media (see, for example, regular updates posted on the Telework, Telecottage and Telecentre Association, http://www.tca.org.uk). Adverts for mobile telephones and computer equipment regularly portray working at home and for several years British Telecom has been promoting its benefits. Furniture manufacturers have introduced popular lines to cater for the office under the stairs or in the spare bedroom (see http://wfh.co.uk). Forecasters and futurologists have produced bullish estimates that suggest anything between a quarter and a half of the workforce will be home-based (Scase 1999; Lees 1999). The barrage of requests for information received by the Department for

Alan Felstead is Reader in Employment Studies at the Centre for Labour Market Studies, University of Leicester. Nick Jewson is Senior Lecturer at the Department of Sociology, University of Leicester. Annie Phizacklea is Professor of Sociology at the Department of Sociology, University of Warwick. Sally Walters is a Research Associate at the Centre for Labour Market Studies, University of Leicester. 
Education and Employment (DfEE) further attests to the interest and importance of the subject for labour market analysts (Employment Gazette 1994: LFS4).

All this interest suggests that there is a need for a reliable statistical portrait of people who work at home. However, conclusions based on regularly produced national data sets are problematic in various ways. Even when thoroughly analysed, some suffer from a number of inherent drawbacks. The 1991 census and the associated Samples of Anonymised Records (SARs) fall into this category. Both the raw and edited census data for 1991 have been extensively analysed, while the SARs have been used to paint a more detailed picture of the characteristics of those reporting that they work 'mainly at home' (Felstead and Jewson 1995 and 1996; Hakim 1998: chapter seven). Furthermore, comparison with previous census records for 1971 and 1981 has provided a basis on which to track trends over time (cf. Hakim 1980:1105; Pugh 1984 and 1990). However, the census material depends upon respondents ticking the 'works mainly at home' box when questioned about their means of travel-to-work. This results in imprecision about where the work is actually conducted since it tends to conflate those who work at and nearby home. This is a major drawback because a key feature of working at home is the overlap of the worlds of work and domestic life - the experience of being 'in work at home' (Felstead and Jewson 2000). This is at its greatest when work is carried out in the spaces where people conduct their daily lives - bedrooms, kitchens, dining rooms and so on. Another problem is that census data are only collected once every ten years, thereby limiting their claims to provide an up-to-date portrayal of the phenomenon. Furthermore, the census is designed to cover a wide range of issues but with a limited number of questions. Although it is possible to embellish the data with proxy information from other sources, direct labour market indicators are in short supply (see Hakim 1998: chapter one).

Somewhat surprisingly, the Labour Force Survey (LFS), which suffers far less from these drawbacks, has only recently been the focus of attention, despite collecting data on this issue since 1992. Attempts have been made to operationalise various definitions of 'homeworking' and 'teleworking' using the LFS (Felstead 1996; Huws et al. 1999:14-22; Mitel 1999:Appendix C). However, analysis has often been restricted to a limited number of issues (e.g. Labour Market Trends 1999 and 2000; President of the Board of Trade 1998:141). Such cursory and incomplete treatments leave considerable scope for further examination of the LFS. Of particular interest is the light it can shed on some of the controversies that bedevil debates about this form of employment. The aim of this paper is to provide such an analysis based on data collected for the LFS in the United Kingdom.

The paper first outlines some of the key controversies in the literature and identifies seven hypotheses which the paper sets out to test. It then discusses the nature of the LFS data, the procedures used and the protocols adopted in the analysis. Following this the results of the analysis are presented and discussed. 


\section{Issues and Controversies: Framing Hypotheses}

The working at home debate is characterised by two conflicting images (Felstead and Jewson 1999 and 2000). On the one hand, there is the image is of a woman tied down by the needs of her family, exploited by her employer, with few or no skills and working for low wages on tedious, repetitive tasks. The most disadvantaged groups in the labour market - such as ethnic minorities - are often seen as the most likely participants in this type of work. In addition, wages are seen as erratic and employment status uncertain. On the other hand, working at home is sometimes perceived in an entirely different light. In this scenario workers have the ability to exercise choice over their employment options, enjoy high paid jobs and possess high level qualifications. This image is often portrayed as the future of work, in which paid employment will be conducted by fax, telephone, email and computer links while at home.

Many of the controversies which surround working at home are, to a large extent, inherent in the conflicts and contradictions these images generate. One way of resolving these conflicting accounts is to distinguish carefully between categories of people who work at home according to their social relations of production. This suggests that the two images refer to workers who occupy entirely different positions in the production process. For example, those who work at home by selling the products of their labour directly to clients or end-users are in a fundamentally different position to those who receive a wage or salary in exchange for their labour. Similarly, within the latter group there are those with relatively high discretion and those with relatively low discretion. This refers to the extent to which qualities of judgement, problem-solving, decision-making and originality are key attributes of the labour process. Low discretion work is predictable, routine, standardised and rule-dominated. In earlier research we have designated those with jobs of this kind as 'homeworkers' (Felstead and Jewson 1997 and 200o) and we will continue to use this terminology here. High discretion work is variable, complex, creative and choicedominated. Unfortunately, when analysing large scale data sets the concept of discretion can, in practice, only be roughly operationalised as a division of occupational types: in descending order, professional, managerial, craft, clerical and routine manual or more crudely, non-manual versus manual. These can only represent a proximate mapping of the discretion levels involved.

These debates and controversies suggest seven key hypotheses that cry out for statistical examination using robust data. Foremost among these is the current extent and recent growth of the phenomenon. As we have already noted a number of heroic predictions have been made - are these borne out by the LFS? One of the key drivers for the growth of working at home is often said to be the information and communication technology (ICT) revolution. Ever since the advent of the word processor in the early 1980s, there has been a keen interest in the link between 
technology and the ability to work in spaces and places previously separated from the workplace, most notably the home (Bisset and Huws 1984; Huws 1984). Subsequent developments in ICT have, if anything, made the blurring of home/work boundaries even greater. Through the use of email, workers can keep in close and personalised contact with clients, colleagues and supervisors despite geographical separation (Cairncross 1997; Coyle 1997). Similarly, using the Internet, workers can access from their homes massive databases and sources of information held on network servers. The growth of ICT has been phenomenal. In 1990 there were 120 million personal computers (PCs) and 2.6 million Internet users worldwide. By 1998 these figures had risen to 370 million and 141 million respectively. Forecasters predict that there will be 670 million PCs and 450 million Internet users by 2002 (ITU 1999). This kind of evidence has led to predictions that in the future more and more people will be working at home. For example, the Henley Centre estimates that a third (31.5 per cent) of people in the UK will work at home to varying degrees by 2006 (Lees 1999). For others, too, there is a strong link between working at home and ICT as the key facilitating device (e.g. Huws et al. 1999; Baines 1999). According to one survey, over 9 million Europeans actively use network technology to carry out their work away from the office - either on the move or at home (European Commission 1999: chapter three). The hypothesis emerging from this evidence, then, is that the use of information and communications technology is strongly associated with those who work at home.

The perception that working at home is synonymous with low pay and poor conditions of employment is commonplace among those convinced of the pessimistic scenario identified above. However, the research evidence in support of this view has rarely come from official national data sets since many of them do not collect useable pay data. Instead figures are largely drawn from smaller scale surveys, some of which have a local focus which have collected data by door-knocking, making direct appeals or chasing known points of contact (Felstead and Jewson 2000:chapter six).

Without doubt, pay rates are headlined by researchers and those who lobby on behalf of homeworkers. Survey after survey has shown that pay is low, both as measured against workers doing similar jobs and against standard indices of low pay. For example, in toy manufacturing, it was found that 82 per cent of homeworkers in Britain earned less than the statutory minimum rates in force at the time (ACAS 1978:45). A survey of wages in the clothing industry found eight times as many homeworkers as on-site workers with rates of pay below the minimum specified for the industry (Hakim and Dennis 1982). Some surveys have uncovered very low rates of pay indeed. For example, Brown (1974:8-10) found homeworkers crocheting baby boots and knitting Arran sweaters for just one-twentieth of the average hourly rate of pay for manual work at the time. This finding is corroborated by studies using a range of different ways of collecting data. These include radio appeals (Brown 1974), 
adverts in the printed media (Crine 1979; Huws 1984; Bisset and Huws 1984), publicity campaigns (Huws 1994; Phizacklea and Wolkowitz 1995) and doorstep surveys (Hope et al. 1976; Allen and Wolkowitz 1987; Felstead and Jewson 1996 and 1997). Similarly, the National Homeworking Survey of 1981 found that almost seven out of ten (69 per cent) of those working at home in manufacturing were low paid according to a definition used at the time (Hakim 1987:106).

Taken together these studies suggest two senses in which homeworkers may be said to be poorly paid. The first compares their pay levels with those of the entire labour force. This is an absolute measure of pay which confirms that homeworkers are among the worst off. The second focuses on relative disadvantage by making comparisons with workplace-located peers. It is in this second sense that research in the US suggests that those who work at home in white-collar jobs enjoy poorer terms and conditions than those of their workplace-located counterparts. In this regard, they may be described as disadvantaged relative to their peers (Kraut and Grambsch 1987). Professionals and managers who work at home in high discretion occupations typically earn more than homeworkers as we have defined them (Hakim 1987), but their remuneration may fall below that of office-located colleagues and their career opportunities may be narrower.

Two main hypotheses emerge from this aspect of the literature. First, absolute levels of low pay are most likely to be found among 'homeworkers' as we have defined them (i.e. low discretion wage labourers). Second, all those who work at home in whatever capacity are likely to pay for the privilege in terms of reduced rates of pay when related to comparable others. This means that working at home is associated with relative disadvantage for all types of job.

The identification of the social characteristics of those who work at home and the organisations for which they work has aroused intense debate. Some researchers assume rather than demonstrate that women are more likely to work at home (e.g. Allen and Wolkowitz 1987); others have a women-only focus (e.g. Christensen 1988; Dawson and Turner 1989; O'Donnell 1987); and there are some who remove men from their sample (e.g. Presser and Bamberger 1993). There is a strong presumption in the literature therefore that working at home is predominately a female activity. The LFS allows us to test this hypothesis.

The issue of ethnicity has also excited heated debate. It has been argued that across the industrialised world working at home is prevalent in regions and areas where recent migrants and ethnic minorities are concentrated (ILO 1989:7). Local campaigning groups and academic researchers in Britain also claim that members of black and Asian communities are over-represented (e.g. Birmingham City Council 1993:3; Elwin 1994:8; Huws 1994:5; Phizacklea and Wolkowitz 1995). The LFS allows us to test whether the association of ethnicity with working at home holds at the national level.

For many writers the heart of the gender issue concerns child care. It is very often 
argued that women take up what may be regarded as a disadvantaged form of employment because of their pressing need to combine earning an income with looking after a young family. This is assumed to be the reason for the presence of women, particularly, among homeworkers. Once again, the LFS provides a national data set on which to test this hypothesis.

\section{Hypotheses}

The above discussion has suggested a number of specific hypotheses which the LFS data can address. These can be stated formally as follows:

1 Working at home is rapidly increasing in its extent.

2 Those working at home are heavily reliant on ICT to carry out their jobs.

3 Homeworkers, as we have defined them, are more likely to be low paid (defined here as less than $\mathfrak{E}_{3} .60$ an hour) than their peers in workplaces.

4 On average, those working at home receive rates of pay lower than comparable others in workplaces.

5 Women are more likely than men to work at home in whatever capacity.

6 Ethnic minorities are more prone to work at home than other ethnic groups.

7 Women with dependent children are more likely to work at home compared with the rest of the population.

The remainder of this paper will explore the strengths and weaknesses of each of these hypotheses. However, before turning to the substantive examination of the evidence it is important to outline the origin and character of the LFS data.

\section{Data Source, Procedures and Protocols}

This paper is based on an analysis of data collected as part of the LFS. Each LFS contains data on a random sample of individuals throughout the United Kingdom. Every quarter almost 60,00o households are contacted and information is collected on a total of 150,00o people. Of this total around 65,000 are 16 and above and are in work.

The design of the LFS involves an element of overlap between survey quarters. Each quarter's sample is made up of five waves, each consisting of about 12,000 households. Every sampled address in a wave is interviewed in five successive quarters, such that in any one quarter, one wave will be receiving their first interview, another their second and so on Thus, there is an 80 per cent overlap between successive quarterly surveys. Certain information is only collected at first interviewfor example, date of birth and ethnic origin. Some data are collected at every interview. Yet other questions - such as those on working at home - are posed at specific intervals. Furthermore, some information is gathered at particular moments 
in the wave cycle - income data, for example, are collected at first and last interviews. The LFS is not, therefore, straightforward. As will be seen, this has implications for the conclusions that can be drawn from the data.

Since 1992, the LFS has distinguished between respondents working mainly and sometimes at home. An additional set of questions, added in Spring 1997, identified those who worked at home at least one full day in the week before interview. They also asked whether the use of a computer and telephone was involved. Answers to these questions, thus, enable us to specify three groups: those who work mainly at home, those who work partially at home (i.e. at least one day a week), and those who work sometimes at home. It has to be said that caution should be applied when interpreting figures for the sometime category - the question asked is open-ended and, by including the phrase 'unpaid work', differs from others asked about working at home.

It should be reiterated that these questions are not asked in every quarterly survey and there have been changes to the frequency of their inclusion. Nevertheless, by picking an appropriate LFS, a general picture of the extent and characteristics of those who, to a greater or lesser extent, work at home can be generated. Furthermore, given the size of the LFS, we are able to provide population estimates for those who work mainly, partially and sometimes at home. The results presented here are based on the Spring 1998 LFS. This contains observations on some 1,698 individuals who work mainly at home, 2,253 who do so on for at least one day a week (i.e. partially) and 14,243 who sometimes work at home. However, breaking down these categories reduces the numbers of observations per cell and their reliability. Advice from the Office for National Statistics (ONS) recommends suppression of data when the number of cases falls to thirty observations (or 10,00o if the data are weighted) (Jenkins 1998).

To operationalise conceptually derived types of home-located working requires further disaggregation. To avoid having to suppress even more data cells, it was decided to aggregate four alternate surveys (Sly 1998). Therefore, the LFS for Spring 1997, Autumn 1997, Spring 1998 and Autumn 1998 were pooled. An unweighted sample of 263,023 working individuals aged 16 and over was created by these means. Of those working mainly at home, 4,159 defined themselves as self-employed and 2,168 considered themselves employees. The latter comprised 1,770 non-manual workers and 397 manual workers - categories which approximate to definitions of 'high discretion' and 'low discretion' labour outlined above and proposed elsewhere (Felstead and Jewson 2000). When aggregating four alternate quarters, ONS suggests a publication threshold of 4,000 cases if the data are weighted to give a population estimate (or 48 individuals if unweighted) (Sly 1999).

Since the LFS contains information on various labour market indicators, aspects of work location and remuneration it offers a unique opportunity to compare the pay of those who work at home with those who work elsewhere. However, in 
interpreting these results it is important to recall that information on pay is based on a sub-sample of the quarterly LFS since this type of data is only collected on entry (wave one) and exit (wave five). Each LFS has around 18,500 pay data observations. Only those who define themselves as employees are asked about pay.

While the quality of the LFS pay data has been questioned (Wilkinson 1998), the fact that more than four-fifths of those working mainly at home supply information in person is likely to enhance its accuracy. This compares to a 65 per cent personal response rate among workplace-located employees. Nevertheless, we adopt advice from ONS which suggests that pay data are unreliable when the number of cases in a single LFS falls to 25 observations (or 30,000 if the data are weighted) (Jenkins 1998). For aggregation of four alternate LFSs these figures equate to a threshold of 40 cases if unweighted or 12,000 if weighted. This protocol is adopted when reporting the pay results from the pooled data set which contains pay information from 74,155 interviewees. Of these, we have information on the pay on 681 employees who work at home, comprising 565 non-manual and 116 manual workers.

\section{Findings}

The issues, hypotheses and technical procedures introduced above form the framework for the following presentation of the results, which provides an overview of frequency tables derived from the LFS (readers seeking more detail are directed towards tables found in Felstead, Jewson, Phizacklea and Walters 200o; also available at: http://www.clms.le.ac.uk/WWW/Readings/Working_Paper_4.pdf).

\section{Extent}

The first task is to estimate the extent of the phenomenon. As we have seen, analysis of LFS data allows us to take a count of the numbers of people working at home on a mainly, partial or sometimes basis.

The numbers working mainly at home jumped over the 1981 to 1998 period rising from 345,920 (1.5 per cent) to 680,612 (2.5 per cent). Unfortunately, similar comparisons over time in the numbers who partially and sometimes work at home are not possible because relevant data have only been collected since Spring 1997 and Spring 1992 respectively. However, figures for Spring 1998 suggest that those partially working at home account for 3.5 per cent of the employed workforce (or 932,364 individuals). While many of these have a workplace to which they mainly report (62.7 per cent), about a third (32.5 per cent) work in different places throughout the working week (i.e. their workplace is fluid and changeable). LFS data also suggest that in Spring 1998 some 21.8 per cent of respondents sometimes worked at home.

Overall, then, the LFS suggests that, in total, more than a quarter of the UK workforce carries out some portion of their work at home - corroborating some of 
the more bullish predictions outlined above. However, this headline figure has to be treated with caution. Clearly most of these people by their own account only work at home sometimes. As already noted in the previous section there must be some concern about the precision and meaning that can be attached to this category. There is no indication of how often, how long and when. Moreover, we do not have any historical trend data on the extent to which the sometimes category has increased or decreased. It is therefore hazardous to draw the conclusion that working at home is rapidly increasing on the basis of this all-inclusive figure. We can only be confident that working mainly at home has increased substantially during the last two decades - but, as we have seen, this only constitutes 2.5 per cent of the employed workforce.

Comparative LFS data are also available on the numbers of workers who report that they have no fixed place to carry out their work. It is not unreasonable to speculate that these people might well conduct some - although probably not most of their work in the home. For example, we might expect them to arrange schedules, make preparations or keep books at home - even if most of their work, such as visiting clients and colleagues, is carried out away from the home. Their number has tripled over the 1981 to 1998 period, rising from 641,900 to $1,824,154$. In 1998 such 'mobile workers' as they are sometimes called, accounted for around 7 per cent of the employed workforce.

\section{Use of information and communications technology}

The extent to which those working at home are dependent on ICT has been invoked, in various ways, to operationalise the concept of 'teleworking' using the LFS data (Labour Market Trends 1999 and 2000; Mitel 1999; Huws et al. 1999). While it is not our intention to follow suit, we do wish to comment on the association between working at home and ICT.

From the Spring 1998 evidence, it appears that those working at home on a partial basis are more dependent on technology as a facilitator of such a working arrangement than those working mainly at home. Just over three out of five (61.2 per cent) of those who work at home on a partial basis use both a telephone and computer, compared to just under a half (49.5 per cent) of those who work mainly at home. Furthermore, almost a half ( 46.8 per cent) of those working partially at home claim it would be impossible without the use of a telephone and a computer, whereas two out of five (39.3 per cent) of those working mainly at home make a similar claim. Not surprisingly, disaggregation shows that it is among non-manual employees that reliance on ICT is greatest. Without use of a computer and telephone over half (50.8 per cent) of them report that they would be unable to operate at home compared to around one in twenty (5.2 per cent) manual employees. Perhaps the surprising feature of this finding is that so many feel that working at home does not depend on ICT. However, the data do not allow comparisons to be made with the employed 
workforce as a whole since the technological dependence questions were only asked of those working at home on a mainly or partial basis. It is, therefore, impossible to use LFS data to test whether ICT is a correlate of working at home. However, if calls for the inclusion of questions on the use of ICT among the employed workforce (e.g. Green et al. 2000) are heeded, then analysis along these lines become a real possibility.

\section{Pay}

Until now only tantalising glimpses of the LFS pay data for those working at home have been in the public domain. For example, the Low Pay Commission reported that a third of employees who work at home would benefit from the introduction of the National Minimum Wage (NMW), at the initial rate of $\mathfrak{E}_{3}$.6o an hour (President of the Board of Trade 1998:141). Given the paucity of information on the pay rates of those working at home (particularly on those we would regard as homeworkers), excavating the LFS pay data provides a unique research opportunity.

A comparative analysis of the pay of those working at home reveals sharp differences. On average, those working at home for at least one day a week are better paid than both those who sometimes and mainly work at home ( $\mathfrak{E}_{13.28}$ an hour versus $\mathfrak{E}_{12} .01$ and $\mathfrak{E}_{10.85}$ respectively). Nevertheless, all are, on average, better paid than employees in general, who receive $\mathfrak{L}_{7.79}$ an hour. There also marked contrasts between non-manual and manual workers. Non-manual workers who work mainly at home, on average, receive rates of pay well above their office-bound colleagues ( $\mathfrak{E} 11.37$ compared to $\mathfrak{E} 9.07$ ). However, manual workers, on average, have rates of pay which are almost half of those who do not work at home ( 22.86 versus $\mathfrak{E}_{5.49}$ ).

In order to confirm these findings separate ordinary least squares (OLS) regressions were carried out for women and men with the dependent hourly wage variable logged to enhance the reliability of the results. A range of control variables were entered in the same way into each of the OLS regressions. After accounting for other factors often considered to affect rates of pay (such as age, sex, qualifications, industry and occupational group) the results suggest that women who undertake non-manual jobs mainly at home receive significantly higher rates of pay than their office-bound counterparts - subsequent calculations suggest a 16 per cent premium. On the other hand, manual women workers receive significantly lower rates of pay than their labour market experience and position would otherwise predict - this translates into a loss of 46 per cent. A different picture emerges for men. Male manual employees receive rates of pay 28 per cent below their factory-based counterparts, while there is no significant association between pay and location among nonmanuals.

Turning to low pay, a quarter (26.1 per cent) of those who work mainly at home are lowly paid, double the proportion of low pay found among employees as whole (13.6 per cent). This finding is broadly in line with those of the Low Pay Commission, 
which was based on an earlier LFS. Moreover, our analysis shows that low pay is particularly associated with those who work mainly at home rather than on a partial (4.5 per cent) or sometimes (3.7 per cent) basis.

The incidence of low pay is alarmingly high among manual workers who work mainly at home - about three-quarters (75.9 per cent) are low paid compared to a fifth (20.9 per cent) of their more conventionally located counterparts. The incidence of low pay is also relatively high among non-manual employees who work mainly at home, where it accounts for a fifth (21.4 per cent) of their number.

Women who work mainly at home have a higher incidence of low pay (32.4 per cent) than female employees more generally (18.8 per cent). However, a similar comparison for men suggests a negligible difference (8.2 per cent and 9.1 per cent respectively). Working at home on a partial or sometimes basis appears to lessen the chances of being among the low paid for both men and women. These figures suggest, then, that there is an association between working at home and low pay especially for women. This impression is further strengthened by other findings. Thus, women make up a high proportion of the lowly paid who work mainly at home - indeed over nine out of ten of these (91.9 per cent) are female. Moreover, logistic regression demonstrates that female manual workers who work mainly at home are no less than ten times more likely to receive low pay than their factorybased counterparts.

It should be noted that the LFS data analysed here predates the introduction of the National Minimum Wage in April 1999, a measure which explicitly identified and covered homeworkers. It might therefore be expected that patterns of low pay have changed in recent times. However, recent research carried out on behalf of the Low Pay Commission indicates that low pay remains extensive among homeworkers in the West Yorkshire textile industry (Low Pay Commission 2000: 106; Gray and Heyes 1999).

\section{Characteristics}

No UK national data source other than the LFS permits an analysis of the characteristics of those who work at home to varying degrees. This provides an important research opportunity that is explored in what follows. The literature often suggests that working at home is predominately undertaken by mothers with young children, the under-qualified, and members of ethnic minorities. However, the LFS data analysed in this paper paints a more complex and variegated picture.

While the results suggest that women outnumber men among those working mainly at home (69.3 per cent versus 30.7 per cent), they also reveal that the opposite is true among those who work at home partially (36.2 per cent versus 63.8 per cent) and sometimes (37.1 per cent versus 62.9 per cent). The overall gender composition of those who work mainly at home shifts dramatically when the category is 
disaggregated by the non-manual/manual divide. Thus, no less than 88.2 per cent of manual employees who work mainly at home are women.

Similarly, qualification levels vary dramatically according to the amount of time spent working at home. Those who work mainly at home have a pattern of qualification levels similar to those of the employed population as a whole. However, there is a different picture for those who work at home partially or sometimes. For example, two out of five (41.0 per cent) of those who work partially at home have degrees compared one in eight (15.6 per cent) of the employed population.

Frequency tables suggest that ethnic minorities are, if anything, under-represented among those who work at home. Ethnic minorities comprise 4.9 per cent of the employed population but only 3.2 per cent of those who work mainly, 3.5 per cent of those who work partially and 2.9 per cent of those who work sometimes at home. However, the data do suggest that they are over-represented among homeworkers, as we have defined them, where they make up 7.1 per cent of the total. Surprisingly, regions with above average concentrations of ethnic minorities in employment (West Yorkshire, West Midlands, Inner and Outer London) are not those in which ethnic minorities are over-represented in the homeworking labour force (although the number of cases falls below reliable levels). Notwithstanding the small number of cases available, figures suggest that ethnic minorities are among the worst paid.

It should be noted a further disaggregation of the category 'ethnic minority' into various black and Asian communities might well reveal differential rates and forms of working at home. Putting together disparate ethnic minority groups may conceal important differences. However, even pooling four LFSs, as this paper has done, does not generate an adequate number of cases to make such an analysis possible. Nevertheless, in principle, this could be achieved by pooling an even greater number of surveys.

At the broadest level, LFS suggests that the presence of dependent children appears to have little association with working at home. For example, a clear majority (59.6 per cent) of those working mainly at home do not have dependent children. Similarly, there is no discernible relationship between the presence of pre-school age children and working at home. However, disaggregation by gender reveals a more varied picture. The proportion of women with pre-school children is higher among those working mainly at home (15.8 per cent) than women in employment (10.2 per cent). The reverse is true for men (6.6 per cent and 12.7 per cent respectively). There is, then, an association between the presence of children and working mainly at home but in different directions for men and women.

Job characteristics can also be analysed. According to the LFS evidence, overall higher occupations and non-manuals are over-represented among those who work at home, while those lower down the occupational hierarchy are under-represented. Around three-fifths (61.9 per cent) of those who mainly work at home consider themselves to be self-employed, whereas a third (32.3 per cent) of those working 
partially, and only a quarter (23.8 per cent) of those who work sometimes, at home define their employment status in similar terms. A majority ( 57.6 per cent) of those who work mainly at home report working part-time, whereas part-time working is less common among other categories of working at home and among the employed population in general. Working at home tends to be over-represented in real estate and business services (this sector covers computer-related activities, management consultancy, accounting and the provision of legal advice). It is under-represented in manufacturing. Similarly, working at home to whatever degree is more prevalent in the South East. Thus, the South East accounts for 41.2 per cent of those who work mainly at home, compared to 32.2 per cent of the employed workforce.

\section{Conclusion}

For a number of years the working at home literature in the UK has been bereft of national official data. A question on workplace location was inserted into the LFS in Spring 1981, but it was then removed for eleven years until its reintroduction in 1992. Since then, a number of authors (e.g. Huws et al. 1999; Felstead 1996) have begun to carry out analysis based on this new source of evidence. However, this paper has sought to take the process a step further by testing seven common hypotheses using LFS-based evidence. These have been derived from a review of the key issues, controversies and debates surrounding working at home.

Our first hypothesis is that working at home is rapidly increasing in its extent. The LFS data analysed here lends some credibility to this hypothesis but also introduces a note of caution. The numbers working mainly at home have increased rapidly over the last two decades but from a very low base (2.5 per cent in 1998). Many of the bolder estimates must be based upon a somewhat nebulous category which refers to the proportions of people working sometimes at home. This concept suffers from a vagueness of definition and lacks an historical benchmark. Nevertheless, it can only be this group that is invoked by claims that up to a quarter of the UK employed workforce is home-located. It is for this reason that we have sought to maintain a distinction in this paper between those working mainly, partially and sometimes at home.

The second major hypothesis addressed is that ICT is a key facilitator of working at home. The data do not allow comparisons to be made with the employed workforce as a whole since the technological dependence questions were only asked of those working at home on a mainly or partial basis. Nevertheless, our findings do not suggest that those working at home are overwhelmingly dependent on ICT. It is true that three out of five of non-manual employees who work mainly at home do use both a telephone and computer. It is perhaps more surprising that a half report that they could work without these devices. Working at home is therefore not simply a product of the ICT revolution. 
The third hypothesis is that those who work at home suffer from absolute disadvantage in the form of low pay. The LFS evidence offers support for this hypothesis. The incidence of low pay is alarmingly high among manual workers who work mainly at home and relatively high among non-manual employees. Multivariate analyses confirms that working mainly at home in whatever capacity is associated with a greater probability of being low paid.

A fourth and related hypothesis is that those working at home receive lower rates of pay than those working in more conventional settings. Our LFS analysis both contradicts and supports this notion of relative disadvantage. Non-manual workers who work mainly at home, on average, receive rates of pay well above their officebound colleagues ( $\mathfrak{E}_{11.37}$ compared to $\mathfrak{E} 9.07$ ). In contrast, manual workers, on average, receive rates of pay which are well below those who do not work at home ( $\mathfrak{E}_{2.86}$ versus $\mathfrak{E}_{5.49}$ ). This pattern is confirmed by multivariate analyses. After controlling for other factors, women who undertake non-manual jobs at home receive a 16 per cent premium, while the location of work makes little difference to the pay male non-manuals receive. On the other hand, both female and male manual workers receive significantly lower rates of pay than their labour market experience would otherwise predict - a 46 per cent and 28 per cent loss respectively.

In some circles it is almost axiomatic to assume that working at home is predominately a female activity - this view informs our fifth hypothesis. Once again, the picture is not always clear-cut and unambiguous. While women outnumber men among those working mainly at home (69 per cent versus 31 per cent), the opposite is true among those who work at home less frequently. The gender balance tips dramatically in women's favour when the focus is on manual employees working mainly at home - in these circumstances, almost nine out of ten are women. This finding is statistically robust - even after holding all other factors constant. Women are significantly more likely to work mainly at home whatever the type of job.

Some writers in the field associate working at home with ethnic minorities - the focus of our sixth hypothesis. The evidence suggests, if anything, that ethnic minorities are under-represented among those working at home. However, this conceals a complex picture in that they are over-represented among those mainly working at home in manual occupations. Moreover, they are among the worst paid.

Our seventh hypothesis is that women with childcare responsibilities are more likely to work at home in order to juggle and meet the demands of all aspects of their lives. For men, childcare responsibilities appear unrelated to the location of their work. However, women who work mainly at home are more likely to report having dependent children than women who work elsewhere. This result is confirmed after controlling for other factors and is statistically significant for all types of job.

This paper has, then, addressed a number of hypotheses using an important national data set which has not been analysed in this way before. Taken together, this evidence highlights the importance of making distinctions between different groups 
of people working at home. It further suggests that the debate between optimistic and pessimistic scenarios fails to disaggregate adequately between different categories of people. Our analysis of the LFS reveals that the social relations of those who work at home are not homogeneous but rather comprise a fragmented and diverse mosaic. Prominent are the cross-cutting divisions of gender, ethnicity, occupation and employment status. In this paper we have particularly focused on two elements of this complex picture that have received scant attention in the past (see, however, Presser and Bamberger 1993). These are: (a) the contrast between non-manual and manual employees who work at home; and (b) the contrast between those who work mainly, partially and sometimes at home. While issues of gender and ethnicity have, rightly, been the focus of interest elsewhere, this paper has sought to add new dimensions and paint a more refined picture.

ACKNOWLEDGEMENTS

Material from the Labour Force Surveys is Crown Copyright and has been made available by the Office for National Statistics (ONS) through the Data Archive and has been used by permission. Neither the ONS nor the Data Archive bear any responsibility for the analysis or interpretation of the data reported here. The paper is based on analysis carried out as part of an ESRC project funded under the Future of Work Initiative - 'Working at Home: New Perspectives' project (L212 25 2022).

REFERENCES

ACAS (1978) Toy Manufacturing Wages Council, report no. 13, London: Advisory, Conciliation and Arbitration Service.

Allen, S. and Wolkowitz, C. (1987) Homeworking: Myths and Realities, London: Macmillan.

Baines, S. (1999) 'Servicing the Media: Freelancing, Teleworking and “Enterprising” Careers', New Technology, Work and Employment, 14:1, 18-31.

Birmingham City Council (1993) Profile of Homeworking Issues in Birmingham, Birmingham: Birmingham City Council.

Bisset, L. and Huws, U. (1984) Sweated Labour: Homeworking in Britain Today, London: Low Pay Unit.

Brown, M. (1974) Sweated Labour: A Study of Homework, London: Low Pay Unit.

Cairncross, F. (1997) The Death of Distance: How the Communications Revolution Will Change Our Lives, London: Orion Business Books.

Christensen, K. (1988) Women and Home-Based Work: The Unspoken Contract, New York: Henry Holt.

Coyle, D. (1997) The Weightless World: Thriving in the Digital Age, London: Capstone.

Crine, S. (1979) The Hidden Army, London: Low Pay Unit.

Dawson, W. and Turner, J. (1989) When She Goes to Work, She Stays at Home: Women, New Technology and Home-Based Work. Canberra: AGPS Press.

Elwin, T. (1994) Outworking: A Code of Practice, Nottingham: Nottingham County Council. Employment Gazette (1994) 'Labour Force Survey: Help-Line’, Employment Gazette, June.

European Commission (1999) Status Report on European Telework: New Methods of Work1999, http://www.eto.org.uk.

Felstead, A. (1996) 'Homeworking in Britain: The National Picture in the mid-199os', Industrial Relations Journal, 27:3, 225-38. 
Felstead, A. and Jewson, N. (1995) 'Working at Home: Estimates from the 1991 Census', Employment Gazette, 103:3, 95-9.

Felstead, A. and Jewson, N. (1996) Homeworkers in Britain, London: HMSO.

Felstead, A. and Jewson, N. (1997) 'Researching a Problematic Concept: Homeworkers in Britain', Work, Employment and Society, 11:2, 327-46.

Felstead, A. and Jewson, N. (1999) 'Domestic Product', People Management, 16 December, 34-6.

Felstead, A. and Jewson, N. (2000) In Work, At Home: Towards an Understanding of Homeworking, London: Routledge.

Felstead, A., Jewson, N., Phizacklea, A. and Walters, S. (2000) 'A Statistical Portrait of Working at Home in the UK: Evidence from the Labour Force Survey', ESRC Future of Work, Working Paper No. 4 (see also: http://www.clms.le.ac.uk/WWW/Readings/Working_Paper_4.pdf).

Gray, A. and Heyes, J. (1999) 'The Impact of the National Minimum Wage on the West Yorkshire Textiles Industry', report to the Low Pay Commission.

Green, F., Felstead, A. and Gallie, D. (2000) 'Computers are Even more Important than you Thought: an Analysis of the Changing Skill-Intensity of Jobs', LSE Centre for Economic Performance Discussion Paper, 439, January.

Hakim, C. (1980) 'Homeworking: Some New Evidence', Employment Gazette, 88:10, 1105-10.

Hakim, C. (1987) 'Home-Based Work in Britain: A Report on the 1981 National Homeworking Survey and the DE Research Programme on Homework', Department of Employment Research Paper, 6 o.

Hakim, C. (1998) Social Change and Innovation in the Labour Market: Evidence from the Census SARs on Occupational Segregation and Labour Mobility, Part-Time Work and Student Jobs, Homework and Self-Employment, Oxford: Oxford University Press.

Hakim, C. and Dennis, R. (1982) 'Homeworking in Wages Council Industries: A Study Based on Wages Inspectorate Records of Pay and Earnings', Department of Employment Research Paper, 37.

Hope, E., Kennedy, M. and de Winter, A. (1976) 'Homeworkers in North London', in D. L. Barker and S. Allen (eds.), Dependence and Exploitation in Work and Marriage, London: Longman.

Huws, U. (1984) The New Homeworkers: New Technology and the Changing Location of White-Collar Work, London: Low Pay Unit.

Huws, U. (1994) Home Truths: Key Results from a National Survey of Homeworkers, Leeds: National Group on Homeworking.

Huws, U., Jagger, N. and O’Regan, S. (1999) 'Teleworking and Globalisation', Institute for Employment Studies Report, 358.

ILO (1989) Home Work: Conditions of Work Digest, Geneva: International Labour Office.

ITU (1999) 'Key Indicators for the World Telecommunication Service Sector', http://www.itu.int/industryoverview/at_glance/KeyTelecom99.htm

Jenkins, J. (1998) 'Expanding the Coverage of Earnings Data in the LFS', Labour Market Trends, 106:4, 157-62.

Kraut, R. E. (1988) 'Homework: what is it and who does it?', in K. E. Christensen (ed.), The New Era of Home-Based Work: Directions and Policies, Boulder, Colorado: Westview Press.

Kraut, R. E. and Grambsch, P. (1987) 'Home-Based White Collar Employment: Lessons from the 1980 Census', Social Forces, 66:2, 410-26.

Labour Market Trends (1999) 'Labour Market Spotlight', Labour Market Trends, October.

Labour Market Trends (2000) 'Labour Market Spotlight', Labour Market Trends, January.

Lees, C. (1999) 'The Age of the Homeworker?', paper presented to the Work at Home Think Tank, Royal College of Art, London, 20 April.

Low Pay Commission (2000) The National Minimum Wage: The Story So Far, Cm 4571, February. 
Mitel (1999) Virtually There - Evolution of Call Centres: A Study into Virtual Call Centres and the Opportunities and Challenges for Teleworkers and Employers, Mitel: Monmouthshire.

O’Donnell, C. (1987) Self-Employed or Employee? A Survey of Women in New South Wales Doing Paid Work at Home, New South Wales: Department of Industrial Relations and Employment.

Phizacklea, A. and Wolkowitz, C. (1995) Homeworking Women: Gender, Ethnicity and Class at Work, London: Sage.

President of the Board of Trade (1998) The National Minimum Wage: First Report of the Low Pay Commission, $\mathrm{Cm}$ 3976, London: Stationery Office.

Presser, H. B. and Bamberger, E. (1993) 'American Women who Work at Home for Pay: Distinctions and Determinants', Social Science Quarterly, 74:4, 815-37.

Pugh, H. S. (1984) 'Estimating the Extent of Homeworking', Social Statistics Research Unit Working Paper, 15 .

Pugh, H. S. (1990) 'Making the Best of a Bad Job: Homeworking in the Secretarial and Clerical Industry', unpublished $\mathrm{PhD}$ thesis, City University, London.

Scase, R. (1999) Britain Towards 2010: The Changing Business Environment, http://www.esrc.ac.uk/2010/docs/britain.html

Sly, F. (1998) 'Averaging Labour Force Survey Data Over Several Quarters', Labour Market Trends, 106:1, 17-22.

Sly, F. (1999) Personal communication with Alan Felstead, 4 August.

TCA (various) TCA OnLine Weekly Updates, Nailsworth: Telework, Telecottage and Telecentre Association.

Wilkinson, D. (1998) ‘Towards Reconciliation of NES and LFS Earnings Data', Labour Market Trends, 106:5, 223-31.

Accepted November 2000

Alan Felstead

Centre for Labour Market Studies University of Leicester 7-9 Salisbury Road LEICESTER LE17QR email:Alan.Felstead@le.ac.uk 